\title{
TXNL1-XRCC1 pathway regulates cisplatin-induced cell death and contributes to resistance in human gastric cancer
}

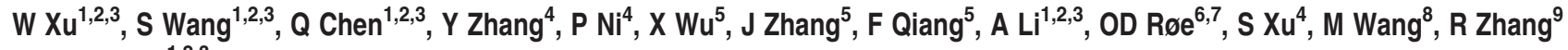 \\ and $\mathrm{J}$ Zhou ${ }^{*, 1,2,3}$
}

Cisplatin is a cytotoxic platinum compound that triggers DNA crosslinking induced cell death, and is one of the reference drugs used in the treatment of several types of human cancers including gastric cancer. However, intrinsic or acquired drug resistance to cisplatin is very common, and leading to treatment failure. We have recently shown that reduced expression of base excision repair protein XRCC1 (X-ray repair cross complementing group1) in gastric cancerous tissues correlates with a significant survival benefit from adjuvant first-line platinum-based chemotherapy. In this study, we demonstrated the role of XRCC1 in repair of cisplatin-induced DNA lesions and acquired cisplatin resistance in gastric cancer by using cisplatin-sensitive gastric cancer cell lines BGC823 and the cisplatin-resistant gastric cancer cell lines BGC823/cis-diamminedichloridoplatinum(II) (DDP). Our results indicated that the protein expression of XRCC1 was significantly increased in cisplatin-resistant cells and independently contributed to cisplatin resistance. Irinotecan, another chemotherapeutic agent to induce DNA damaging used to treat patients with advanced gastric cancer that progressed on cisplatin, was found to inhibit the expression of XRCC1 effectively, and leading to an increase in the sensitivity of resistant cells to cisplatin. Our proteomic studies further identified a cofactor of $26 \mathrm{~S}$ proteasome, the thioredoxin-like protein 1 (TXNL1) that downregulated XRCC1 in BGC823/DDP cells via the ubiquitinproteasome pathway. In conclusion, the TXNL1-XRCC1 is a novel regulatory pathway that has an independent role in cisplatin resistance, indicating a putative drug target for reversing cisplatin resistance in gastric cancer.

Cell Death and Disease (2014) 5, e1055; doi:10.1038/cddis.2014.27; published online 13 February 2014

Subject Category: Cancer

Gastric cancer is the second leading cause of cancer-related deaths worldwide. With an overall 5-year survival rate of only $20 \%$, it becomes a major cause of both morbidity and mortality, ${ }^{1,2}$ where even resectable disease has a $50-90 \%$ risk of recurrence and death. ${ }^{3}$ Adjuvant platinum and fluorouracil or capecitabine-based chemotherapy has been shown to increase survival after gastric resection. However, owing to intrinsic or acquired drug resistance, relapse and metastasis are common. ${ }^{4}$ Multiple mechanisms are known to be involved in drug resistance, including increased drug efflux, altered drug metabolism, enhanced capability of DNA repair, and activation of downstream or parallel signaling pathways. ${ }^{5}$

Cisplatin, one of the most widely used and effective anticancer agents, targets the DNA by inducing DNA adducts and crosslinks, leading to single- and double-strand breaks
(DSBs), activating the DNA damage response, resulting in apoptotic cell death. ${ }^{6}$ Cisplatin is the treatment backbone in a variety of cancers including gastric cancer, ${ }^{7-11}$ but intrinsic and acquired resistance impairs its effectiveness to a high degree. This phenomenon is even common in the adjuvant setting where no macroscopic tumor is evident. Perturbations of DNA repair in tumor, such as increased nucleotide excision repair (NER), inter-strand crosslink repair, non-homologous end-joining (NHEJ), homologous recombination (HR), or loss of mismatch repair, are among the most important mechanisms for cisplatin resistance. ${ }^{12,13}$

$\mathrm{XRCC1}$ (X-ray repair cross complementing group1) is a key mediator of single-strand break (SSB) DNA repair, which includes both base excision repair and NER mechanisms. ${ }^{14}$ XRCC1 interacts with DNA-dependent protein kinase (DNA-PK)

\footnotetext{
${ }^{1}$ Department of Molecular Cell Biology and Toxicology, Key Laboratory of Modern Toxicology (NJMU), Ministry of Education, Nanjing, People's Republic of China; ${ }^{2}$ Jiangsu Key Laboratory of Cancer Biomarkers, Prevention and Treatment, Cancer Center, Nanjing, People's Republic of China; ${ }^{3}$ School of Public Health, Nanjing Medical University, Nanjing, People's Republic of China; ${ }^{4}$ Department of Cell Biology, School of Basic Medical Sciences, Nanjing Medical University, Nanjing, People's Republic of China; ${ }^{5}$ Department of Oncology, Nantong Cancer Hospital, Jiangsu Province, People's Republic of China; ${ }^{6}$ Department of Cancer Research and Molecular Medicine, Norwegian University of Science and Technology, Trondheim, Norway; ${ }^{7}$ Cancer Clinic, LevangerHospital, Nord-Trøndelag Health Trust, Levanger, Norway; ${ }^{8}$ Department of Biomedical Sciences, School of Pharmacy, Texas Tech University Health Sciences Center, Amarillo, TX, USA and ${ }^{9}$ Department of Pharmaceutical Sciences, School of Pharmacy, Texas Tech University Health Sciences Center, Amarillo, TX, USA

${ }^{*}$ Corresponding author: J Zhou, Department of Molecular Cell Biology and Toxicology, School of Public Health, Nanjing Medical University, 140 Hanzhong Road, Nanjing 210029, People's Republic of China. Tel: +86 258686 8421; Fax: +86 258686 2050; E-mail: jwzhou @njmu.edu.cn

Keywords: cisplatin; gastric cancer; drug resistance; XRCC1; TXNL1

Abbreviations: CHX, cycloheximide; DDP, cis-diamminedichloridoplatinum(II); CTR1, copper transporter 1; DNA-PK, DNA-dependent protein kinase; DSB, doublestrand break; FANCD2, Fanconi anemia group D2; GSH, glutathione; HR, homologous recombination; IR, ionizing irradiation; MRP2, multidrug resistance-associated protein 2; NER, nucleotide excision repair; NHEJ, non-homologous end-joining; PARP1, poly(ADP-ribose) polymerase 1; p-CHk1, phosphorylated checkpoint kinase 1; ROS, reactive oxygen species; SSB, single-strand break; TXNL1, thioredoxin-like protein 1; TUNEL, TdT-mediated dUTP nick-end labeling; Ub, ubiquitin; XRCC1, X-ray repair cross complementing group1; $\gamma \mathrm{H} 2 \mathrm{AX}$, phosphorylated histone $\mathrm{H} 2 \mathrm{AX}$

Received 24.9.13; revised 08.1.14; accepted 09.1.14; Edited by H-U Simon
} 
in response to ionizing irradiation (IR) induced DSBs, and thus has a role in NHEJ as well. ${ }^{15}$ We have recently reported that adjuvant platinum-based chemotherapy significantly improves overall survival in gastric cancer patients with low levels of tumoral XRCC1 expression. ${ }^{16}$ Although several studies have suggested an association between XRCC1 and cisplatin resistance, ${ }^{17,18}$ the contribution of $\mathrm{XRCC1}$ to cisplatin resistance in gastric cancer and underlying mechanisms are not fully understood.

The objectives of this study were to investigate the role of XRCC1 in cisplatin resistance of gastric cancer cells and elucidate the underlying mechanisms of action. Here we identified the involvement of the proteasome cofactor thioredoxin-like protein 1 (TXNL1) in XRCC1 degradation and its modulation of cisplatin effect. These findings may benefit gastric cancer treatment in the future, by improved use of existing agents in combination therapy or development of novel targeted therapies.

\section{Results}

Cisplatin-resistant gastric cancer cells BGC823/DDP display enhanced DNA repair capacity. First, a cisplatinresistant cell line BGC823/cis-diamminedichloridoplatinum(II) (DDP) was established by chronic low-dose cisplatin exposure of a primary sensitive gastric cancer cell line BGC823. These two cell lines and a third gastric cancer cell line, MGC803, were used. The viability of the BGC823, BGC823/DDP, and MGC803 gastric cancer cells treated with cisplatin were determined by the CCK-8 assay. The mean $\mathrm{IC}_{50}$ value of cisplatin in BGC823/DDP cells $(16.09 \mu \mathrm{g} / \mathrm{ml})$ was significantly higher than that of their parental BGC823 cells $(0.85 \mu \mathrm{g} / \mathrm{ml}$; Figure 1a), and the calculated resistance index (RI) to cisplatin was 18.9. Interestingly, the $\mathrm{IC}_{50}$ value of cisplatin in MGC803 cells $(2.78 \mu \mathrm{g} / \mathrm{ml})$ was significantly higher than that of the BGC823 cells (Supplementary Figure 1a), indicating that the intrinsic or natural sensitivity to cisplatin differs among various parental gastric cancer cell lines.

To compare DNA lesions in cisplatin-resistant versus cisplatin-sensitive gastric cancer cells, we determined the phosphorylated histone $\mathrm{H} 2 \mathrm{AX}(\gamma \mathrm{H} 2 \mathrm{AX})$, a sensitive surrogate marker of DSB by immunofluorescence staining. The cells were treated with cisplatin at $0.8 \mu \mathrm{g} / \mathrm{ml}\left(\mathrm{IC}_{50}\right.$ of the BGC823) or vehicle control for $24 \mathrm{~h}$. As shown in Figures $1 \mathrm{~b}$ and $\mathrm{c}$, there were more $\gamma \mathrm{H} 2 \mathrm{AX}$-positive cells in the BGC823 cells than that in the BGC823/DDP cells $(P<0.001)$. Western blotting confirmed higher levels of $\gamma \mathrm{H} 2 \mathrm{AX}$ protein in BGC823 cells than BGC823/DDP cells and the MGC803 cells after exposure to cisplatin (Figure 1d, Supplementary Figure 1b). The TdT-mediated dUTP nick-end labeling (TUNEL) assay showed that cell death was increased in BGC823 cells but not in BGC823/DDP cells (Figure 1e). These data indicated that enhanced DNA repair capacity could be one of the major mechanisms for developing cisplatin resistance in gastric cancer.

Overexpression of XRCC1 in BGC823/DDP cells reduces cisplatin-induced cell death. Our previous study demonstrated that platinum-based chemotherapy significantly improves overall survival in gastric cancer patients with low levels of tumoral XRCC1 expression. ${ }^{16}$ To investigate if $\mathrm{XRCC} 1$ independently contributes to cisplatin resistance in gastric cancer cells, we determined the $\mathrm{XRCC1}$ expression in BGC823, BGC823/DDP, and MGC803 cells. The western blotting analyses revealed that the XRCC1 protein levels in BGC823/DDP cells were 6.9-fold higher than that in BGC823 cells (Figure 2a). The MGC803 cells also displayed 1.5-fold higher levels of XRCC1 than that in BGC823 cells (Supplementary Figure 2a). The role of XRCC1 in cisplatin-induced cell death was then detected by CCK-8 assay. The enforced overexpression of XRCC1 in BGC823 cells by transfection of RFP-XRCC1 plasmid resulted in reduced cell death induced by cisplatin, compared with the cells treated with vector control; and the mean $\mathrm{IC}_{50}$ value to cisplatin was $1.4 \mu \mathrm{g} / \mathrm{ml}$ in RFP-XRCC1-transfected BGC823 cells, significantly higher than that of control BGC823 cells (to $0.84 \mu \mathrm{g} / \mathrm{ml}$; Figure 2b). Furthermore, knockdown of XRCC1 in BGC823/DDP cells by transfection of XRCC1 shRNA plasmid resulted in increased cell death induced by cisplatin. The mean $\mathrm{IC}_{50}$ value of cisplatin was $10.98 \mu \mathrm{g} / \mathrm{ml}$ in shXRCC1-transfected BGC823/DDP cells, compared with $14.76 \mu \mathrm{g} / \mathrm{ml}$ of the cells treated with control shRNA (Figure 2c). Furthermore, the long-term clonogenic survival assay supported the data from the short-term cell survival CCK-8 assay, indicating that overexpression of XRCC1 enhanced the survival of BGC823 cells (Figures 2d and e), while knockdown of XRCC1 in BGC823/DDP cells decreased their survival in response to cisplatin (Figures $2 f$ and g). These data indicated that XRCC1 expression levels in gastric cancer cells are closely linked to their resistance to cisplatin.

XRCC1 restrains cisplatin-induced cell death through regulation of DNA damage-induced apoptosis. In line with the results showing that $\mathrm{XRCC} 1$ restrains cisplatininduced cell death, the significantly reduced $\gamma \mathrm{H} 2 \mathrm{AX}$ levels were found in XRCC1 overexpressed BGC823 cells (RFP$\mathrm{XRCC} 1)$ treated with $0.8 \mu \mathrm{g} / \mathrm{ml}$ of cisplatin for $24 \mathrm{~h}$ compared with control cells $(P<0.001$; Figures $3 a-c)$. In addition, it was shown that $\gamma \mathrm{H} 2 \mathrm{AX}$ levels were increased in XRCC1 knockdown BGC823/DDP cells (Figures 3d-f) and MGC803 cells (Supplementary Figure $2 \mathrm{~b}$ ) when cells were treated with cisplatin for $24 \mathrm{~h}(P<0.001)$. The TUNEL assay also showed that the cell death was significantly decreased $(P<0.01)$ in XRCC1 overexpressed BGC823 cells treated with $0.8 \mu \mathrm{g} / \mathrm{ml}$ of cisplatin for $48 \mathrm{~h}$, compared with the control cells (Figures $3 \mathrm{~g}$ and $\mathrm{h}$ ). Moreover, western blotting confirmed that the overexpression of XRCC1 significantly decreased cleaved form $(89 \mathrm{kDa})$ of poly(ADP-ribose) polymerase 1 (PARP1) protein relative to the control cells in response to cisplatin (Figure $3 \mathrm{i}$ ), which served as a biomarker of apoptosis. In contrast, knockdown of XRCC1 in BGC823/DDP cells by XRCC1 siRNA significantly increased the cell death $(P<0.01$; Figures $3 \mathrm{j}$ and $\mathrm{k})$ and the levels of cleaved PARP1 (Figure 3l), compared with siRNA control cells exposed to $5 \mu \mathrm{g} / \mathrm{ml}$ of cisplatin for $48 \mathrm{~h}$. We also used the XRCC1deficient Chinese hamster cell line EM9 to confirm the role of $\mathrm{XRCC} 1$ in regulating cisplatin resistance. Our results showed significantly more surviving cells and less cleaved PARP1 in 


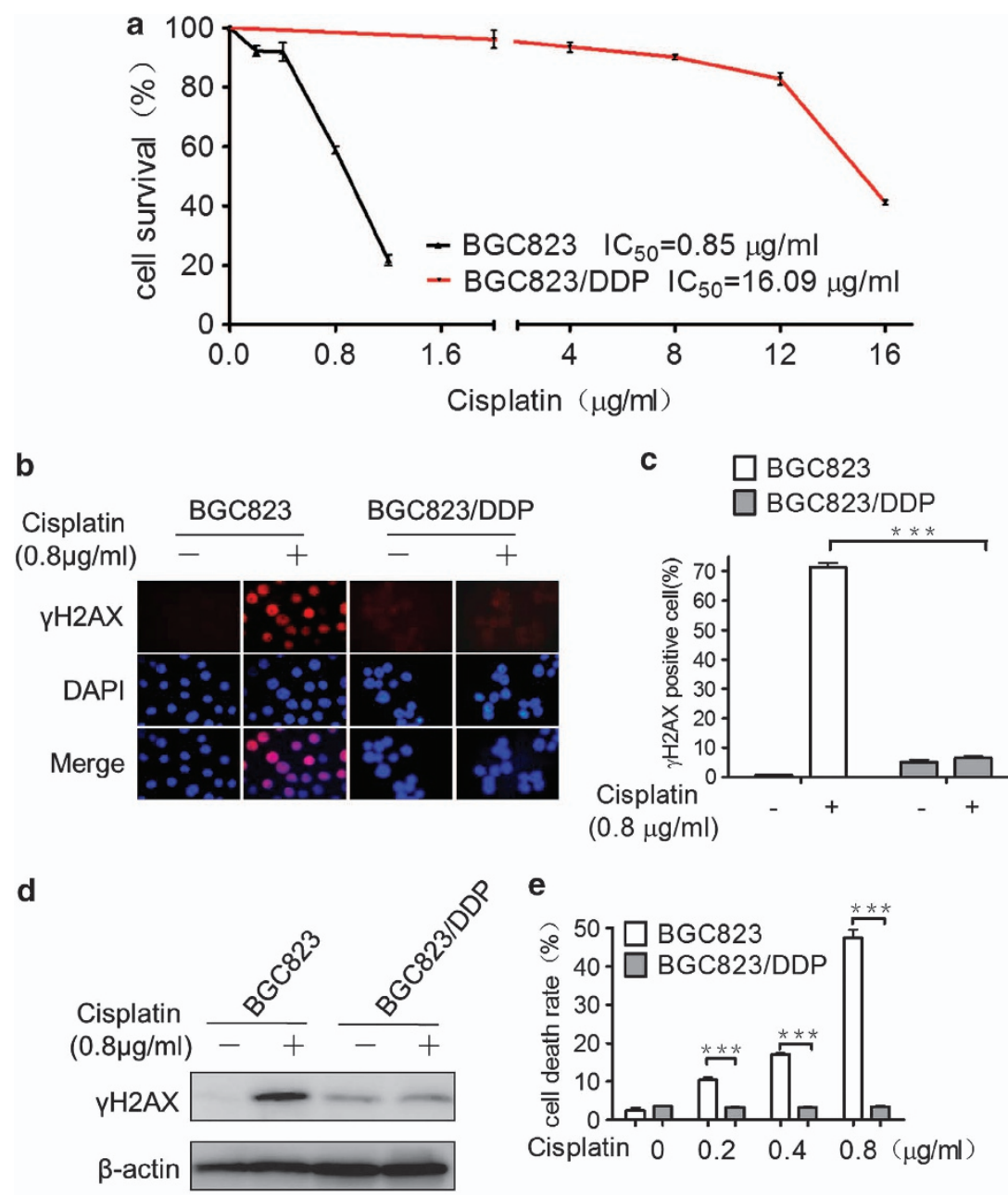

Figure 1 Acquired cisplatin-resistant BGC823/DDP cells showed enhanced DNA repair capacity. (a) The cell viability was determined by exposure of BGC823 and BGC823/DDP cells to cisplatin for $48 \mathrm{~h}$. $\mathrm{RI}=\mathrm{IC}_{50}$ of resistant cells/IC $\mathrm{I}_{50}$ of sensitive cells. (b) Immunofluorescence staining determined $\gamma \mathrm{H} 2 \mathrm{AX}$ foci by exposure of BGC823 and BGC823/DDP cells to $0.8 \mu \mathrm{g} / \mathrm{ml}$ of cisplatin for $24 \mathrm{~h}(\times 1000)$. (c) Quantification of $\gamma \mathrm{H} 2 \mathrm{AX}$ foci-positive cells. The cells with $\gamma \mathrm{H} 2 \mathrm{AX}$ foci $>5$ were counted as positive cells and expressed as a percentage. (d) $\gamma \mathrm{H} 2 \mathrm{AX}$ levels was determined by western blotting. The BGC823 and BGC823/DDP cells were exposed to $0.8 \mu \mathrm{g} / \mathrm{ml}$ of cisplatin for $24 \mathrm{~h}$. The level of each protein was normalized against $\beta$-actin. (e) Cell death was determined by TUNEL assay. The BGC823 and BGC823/DDP cells were exposed to $0.8 \mu \mathrm{g} / \mathrm{ml}$ of cisplatin for $48 \mathrm{~h}$. Results are representative of at least three independent experiments and shown as the mean \pm S.D. ${ }^{* \star \star} P<0.001$

cisplatin-treated EM9 cells transfected with the RFP-XRCC1 plasmid (Supplementary Figures $3 a-c$ ). These data suggested that intracellular XRCC1 expression levels are negatively associated with the levels of cisplatin-induced DNA damage and apoptosis.

XRCC1 colocalized with DNA-PK in response to cisplatininduced DNA lesions. To compare the differential responses between the BGC823 and BGC823/DDP cells to cisplatin treatment, we further determined protein expressions of important DNA repair proteins, DNA-PK, phosphorylated checkpoint kinase 1 ( $p-C H K 1)$, Fanconi anemia group D2 (FANCD2), and XRCC1. The data showed lower background levels of $\mathrm{p}-\mathrm{CHK} 1, \mathrm{FANCD} 2$, DNA-PK, and XRCC1 in the parental BGC823 cells compared with that in BGC823/ DDP cells. When the BGC823 cells were treated with cisplatin at $\mathrm{IC}_{50}(0.8 \mu \mathrm{g} / \mathrm{ml})$, the expressions of these molecules increased slowly and finally showed obvious DSB with enhanced $\gamma \mathrm{H} 2 \mathrm{AX}$ levels (Figures $4 \mathrm{a}$ and $\mathrm{b}$ ).
In the BGC823/DDP cells, however, a completely different response was observed, showing that DNA-PK, and XRCC1 persistently displayed higher expressions after treatment with $0.8 \mu \mathrm{g} / \mathrm{ml}$ of cisplatin, whereas both $\mathrm{p}-\mathrm{CHK}$ and FANCD2 showed a gradually reduced expression pattern and undetectable DSB during the exposure (Figure 4a). However, when the concentration of cisplatin was increased to $10 \mu \mathrm{g} / \mathrm{ml}$ for $24 \mathrm{~h}$, the BGC823/DDP cells showed significant DSB, and the expressions of all these molecules also increased slowly in response the DSB (Figure 4a). These data demonstrated a totally different response threshold of DNA repair signal pathway to cisplatin treatment exists between the sensitive and resistant gastric cancer cells. Our data also showed that cisplatin-triggered XRCC1 and DNA-PK were colocalized in both BGC823 and BGC823/DDP cells (Figures 4b and c). This effect was also confirmed in EM9 cells, showing that the transfected GFP-XRCC1 was colocalized with intrinsic DNA-PK after treatment with cisplatin (Supplementary Figure 3c). These results suggested that the interactions between 
a

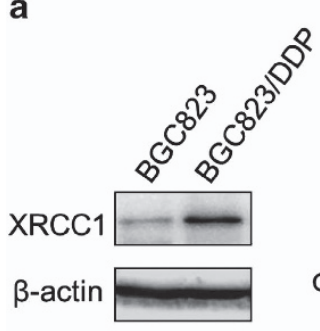

b

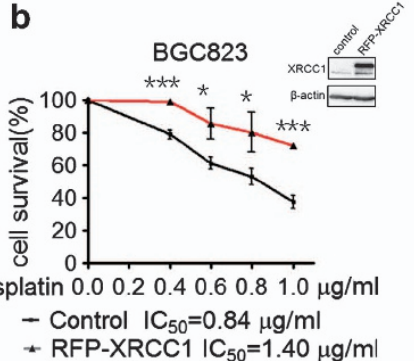

C

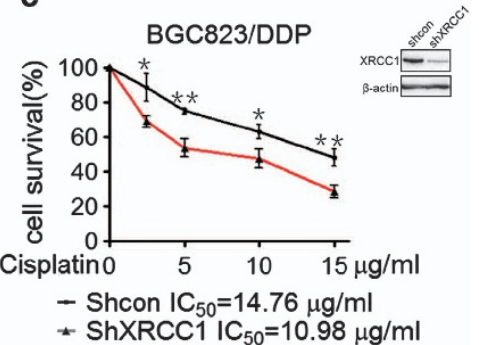

d

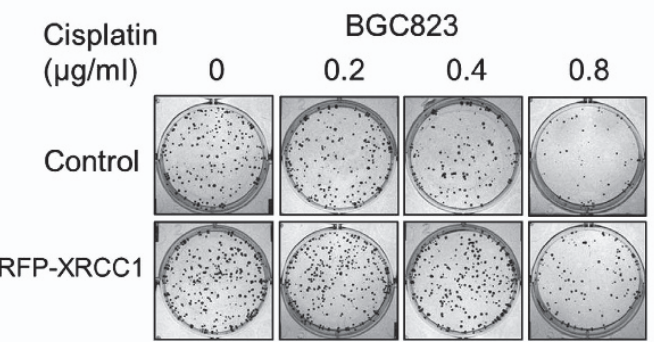

f

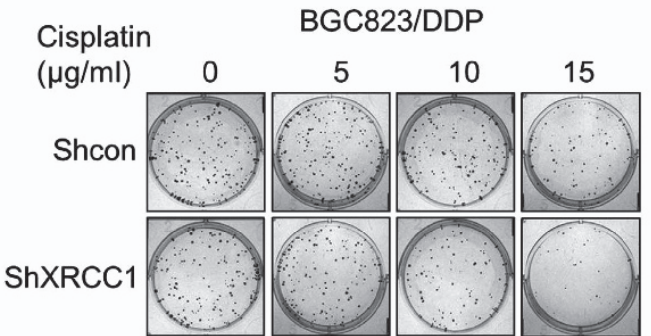

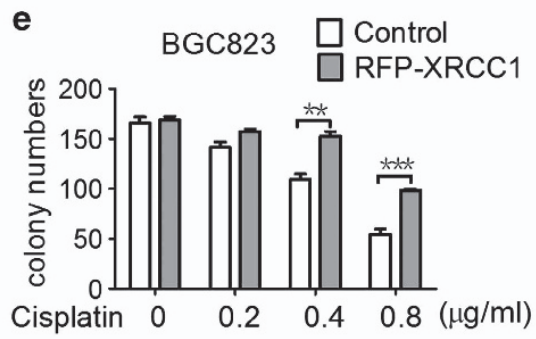

g

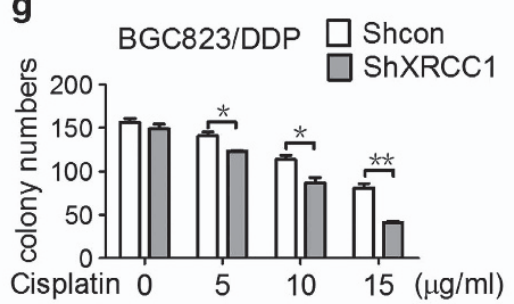

Figure 2 The XRCC1 levels are elevated in cisplatin-resistant gastric cancer cells and mediate resistance to cisplatin. (a) The XRCC1 expression in BGC823 and BGC823/DDP cells was analyzed by western blotting. (b) The viability of BGC823 cells transfected with RFP-XRCC 1 for $48 \mathrm{~h}$ followed by exposure to $0,0.4,0.6,0.8$, or $1.0 \mu \mathrm{g} / \mathrm{ml}$ of cisplatin for $48 \mathrm{~h}$ was determined by CCK-8 assay. (c) The viability of BGC823/DDP cells transfected with XRCC1 shRNA for $48 \mathrm{~h}$ followed by exposure to $0,2.5,5,10$, or $15 \mu \mathrm{g} / \mathrm{ml}$ of cisplatin for $48 \mathrm{~h}$ was determined by CCK-8 assay. (d) BGC823 cells transfected with RFP-XRCC 1 for $48 \mathrm{~h}$ were subjected to clonogenic survival assay 2 weeks after treatment with $0,0.2,0.4$, or 0.8 of $\mu \mathrm{g} / \mathrm{ml}$ of cisplatin for $2 \mathrm{~h}$. (e) Quantify numbers of colony in BGC823 cells transfected with RFP-XRCC1, each colony containing cells $>50$ were counted. (f) The BGC823/DDP cells transfected with XRCC1 shRNA for $48 \mathrm{~h}$ were subjected to clonogenic survival assay 3 weeks after treatment with $0,5,10$, or $15 \mu \mathrm{g} / \mathrm{ml}$ of cisplatin for $2 \mathrm{~h}$. (g) Quantification of colonies in BGC823/DDP cells transfected with XRCC1 shRNA, each colony containing $>50$ cells were counted. Results are representative of at least three independent experiments and shown as the mean \pm S.D. ${ }^{*} P<0.05,{ }^{\star \star} P<0.01,{ }^{* \star} P<0.001$

XRCC1 and DNA-PK may be important in cisplatin-resistant gastric cancer cells.

Irinotecan inhibits the expression of XRCC1 and enhances cisplatin-induced cell death in BGC823/DDP cells. Irinotecan, a topoisomerase-1 (TOP-1) inhibitor, is often used after failure of first-line cisplatin-based treatment in the clinic. ${ }^{19}$ However, the mechanism of action remains unclear. In this study, we investigated the effect of irinotecan on cisplatin-resistant gastric cancer cells. As shown in Figure $5 \mathrm{a}$, the $\mathrm{IC}_{50}$ values of irinotecan were 57.49 and $87.24 \mu \mathrm{g} / \mathrm{ml}$ in BGC823 cells and BGC823/DDP cells, respectively. When the BGC823/DDP cells were treated with a combination of $60 \mu \mathrm{g} / \mathrm{ml}$ of irinotecan and $5 \mu \mathrm{g} / \mathrm{ml}$ of cisplatin for $48 \mathrm{~h}$, the cell survival rate was significantly reduced compared with the cells treated with either drug alone (Figure 5b). This effect was also confirmed in MGC803 cells treated with $0.8 \mu \mathrm{g} / \mathrm{ml}$ of cisplatin and $60 \mu \mathrm{g} / \mathrm{ml}$ of irinotecan for $48 \mathrm{~h}$ alone or in combination $(P<0.001$; Supplementary Figure 4a). Accordingly, the significantly enhanced $\gamma \mathrm{H} 2 \mathrm{AX}$ levels were also found in BGC823/DDP cells treated with irinotecan plus cisplatin compared with irinotecan alone $(P<0.001$; Figures $5 \mathrm{c}$ and d). Interestingly, the cisplatin-resistant gastric cancer cells treated with irinotecan for $24 \mathrm{~h}$ showed significantly reduced expression of XRCC1 (Figure 5e), and this phenomenon was also observed in the MGC803 cells (Supplementary Figure 4b). We then treated BGC823/DDP cells with $5 \mu \mathrm{g} / \mathrm{ml}$ of cisplatin or with $60 \mu \mathrm{g} / \mathrm{ml}$ of irinotecan to determine time-response effects. As a result, XRCC1 was induced by cisplatin treatment in a time-dependent manner whereas inhibited by irinotecan treatment (Figure 5f). Accordingly, significantly enhanced $\gamma \mathrm{H} 2 \mathrm{AX}$ levels in a time-dependent manner were observed by treatment of cisplatin and irinotecan alone or in combination (Figure 5f). Furthermore, overexpression of XRCC1 in BGC823/DDP cells by transfection of RFPXRCC1 plasmid resulted in decreased $\gamma \mathrm{H} 2 \mathrm{AX}$ levels by treatment of cisplatin and irinotecan in combination (Figure $5 \mathrm{~g}$ ). A more in-depth mechanism analysis showed that ubiquitinated XRCC1 was increased by treatment of cisplatin and irinotecan in combination (Figure $5 \mathrm{~h}$ ). When the cells treated with proteasome inhibitor PS-341 of $50 \mu \mathrm{M}$ for $6 \mathrm{~h}$, the XRCC1 expression was effectively rescued. At the same time, ubiquitinate XRCC1 was increased because of 
a

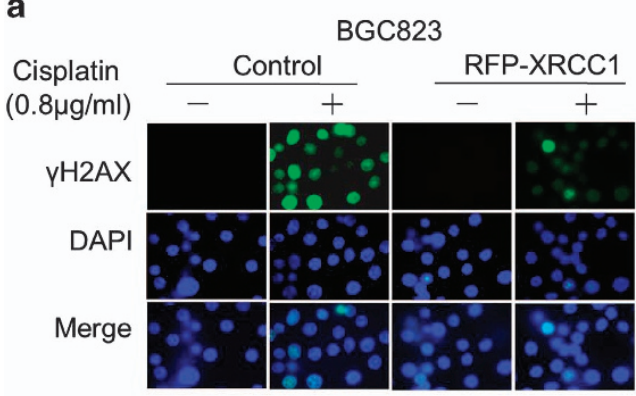

d

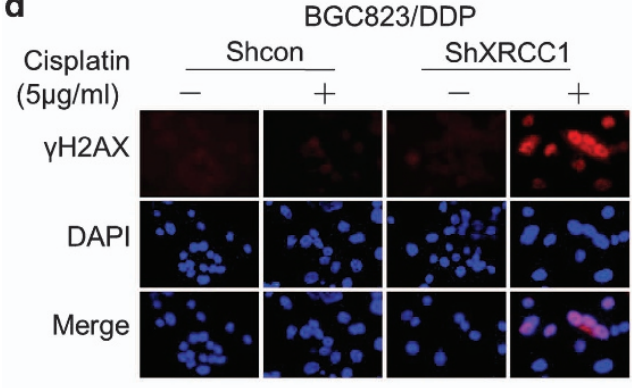

b

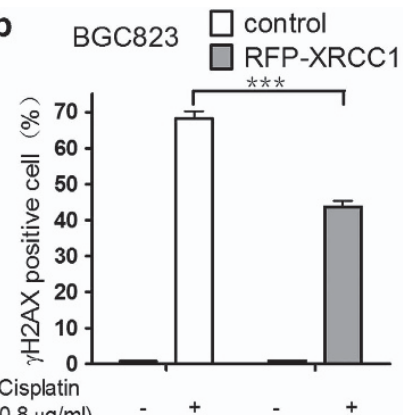

e
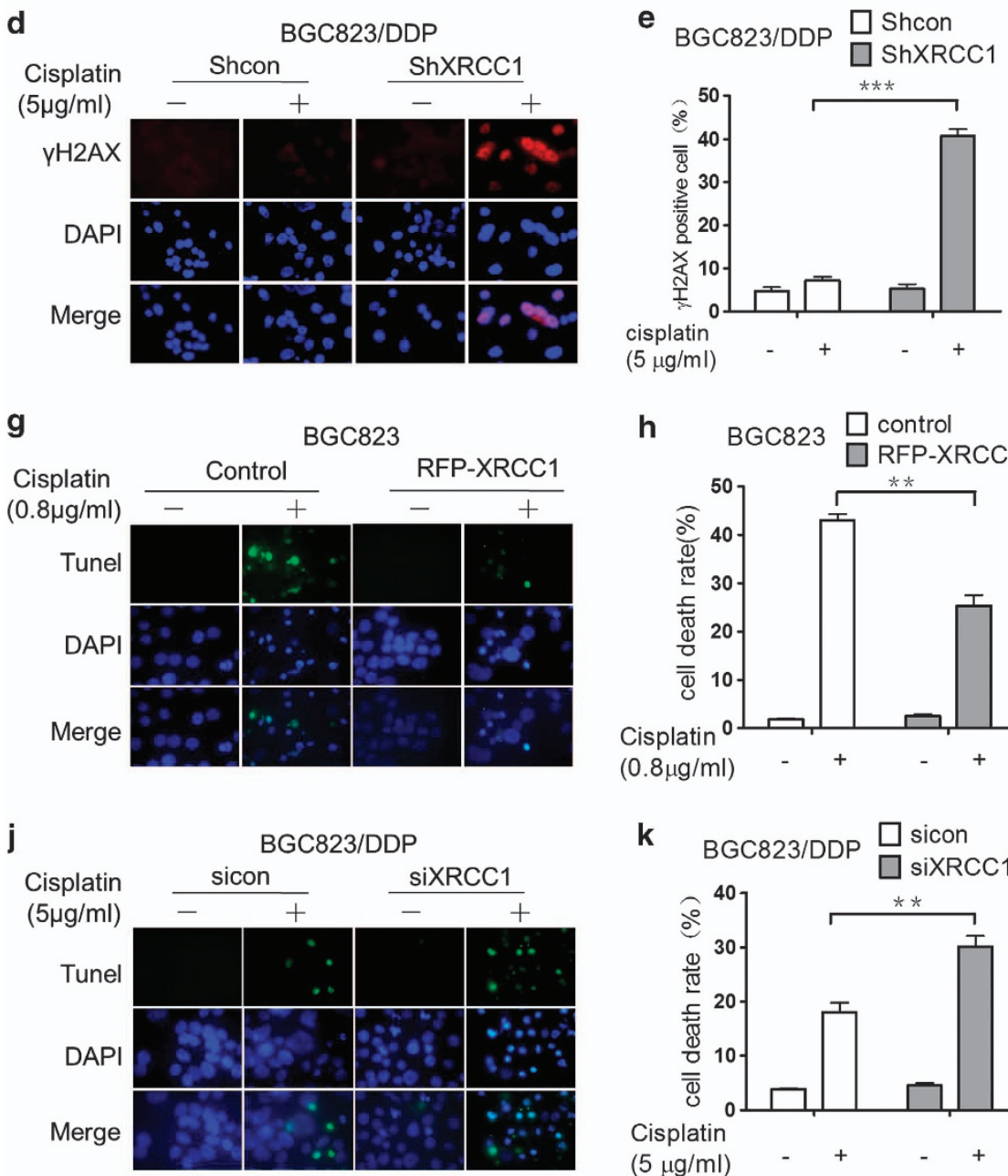

h

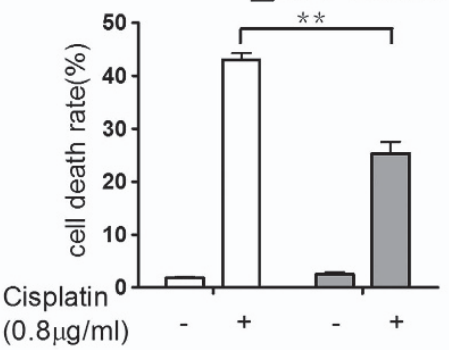

k

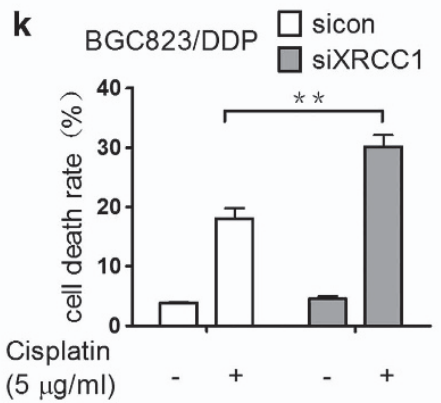

C

BGC823

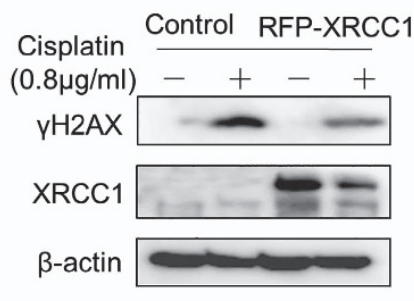

f

\section{BGC823/DDP}

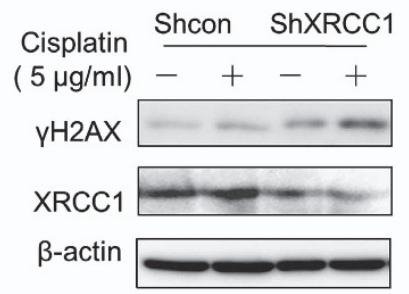

Figure 3 XRCC1 restrains cisplatin-induced cell death by regulation of DNA damage-induced apoptosis. (a) The BGC823 cells transfected with RFP-XRCC1 for $48 \mathrm{~h}$ followed by exposure to $0.8 \mu \mathrm{g} / \mathrm{ml}$ of cisplatin for additional $24 \mathrm{~h}$, and analyzed by $\gamma \mathrm{H} 2 \mathrm{AX}$ foci staining. (b) Quantify $\gamma \mathrm{H} 2 \mathrm{AX}$ foci-positive cells of BGC823 cells transfected with RFP-XRCC1. The cells with $\gamma \mathrm{H} 2 \mathrm{AX}$ foci $>5$ were counted as positive cells and expressed as a percentage. (c) Western blotting to determine the expression of XRCC1 and $\gamma \mathrm{H} 2 \mathrm{AX}$ in BGC823 cells transfected with RFP-XRCC1. (d) BGC823/DDP cells transfected with XRCC1 shRNA for $48 \mathrm{~h}$ followed by exposure to $5 \mu \mathrm{g} / \mathrm{ml}$ of cisplatin for additional $24 \mathrm{~h}$ to give $\gamma \mathrm{H} 2 \mathrm{AX}$ foci staining. (e) Quantify $\gamma \mathrm{H} 2 \mathrm{AX}$ foci-positive cells of BGC823/DDP cells transfected with XRCC1 shRNA. The cells with $\gamma \mathrm{H} 2 \mathrm{AX}$ foci $>5$ were counted as positive cells and expressed as a percentage. (f) Western blotting to determine the level of XRCC1 and $\gamma$ H2AX in BGC823/DDP cells transfected with XRCC1 shRNA. (g) The BGC823 cells transfected with RFP-XRCC1 $48 \mathrm{~h}$ followed by exposure to $0.8 \mu \mathrm{g} / \mathrm{ml}$ of cisplatin for $48 \mathrm{~h}$, and the cell death rate was determined by the TUNEL assay $(\times 1000)$. (h) Quantification of TUNEL-positive BGC823 cells transfected with RFP-XRCC1. (i) Western blotting was applied to determine the level of cleaved forms of PARP1 in BGC823 cells transfected with RFP-XRCC1. (j) The BGC823/DDP cells transfected with XRCC1 shRNA for $48 \mathrm{~h}$ followed by exposure to $5 \mu \mathrm{g} / \mathrm{ml}$ of cisplatin for $48 \mathrm{~h}$, and using TUNEL assay to determine the cell death rate. (k) Quantify TUNEL-positive cells of BGC823/DDP cells transfected with shXRCC1. (I) Western blotting was used to determine the level of cleaved forms of PARP1. Results are representative of at least three independent experiments and shown as the mean \pm S.D. ${ }^{* *} P<0.01$, ${ }^{* * *} P<0.001$ 
a

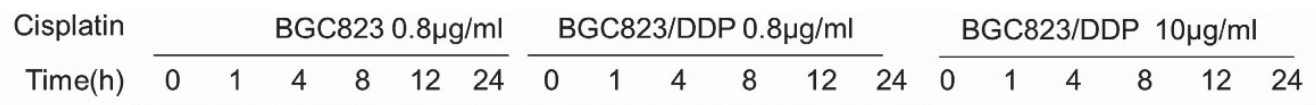
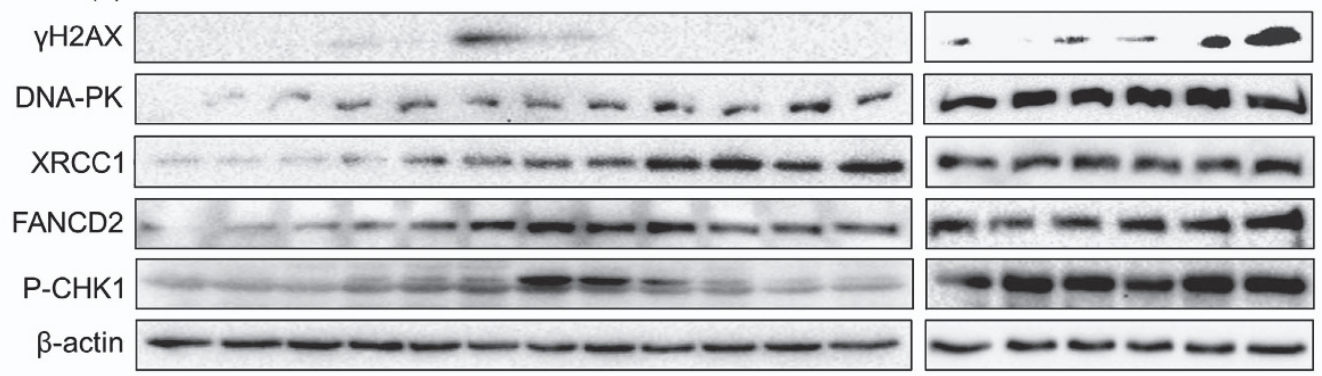

b

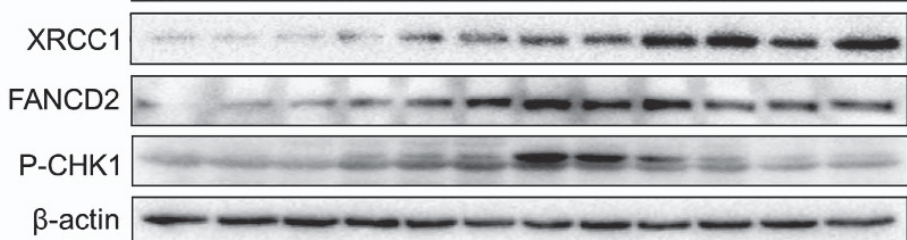

BGC823 treated with $0.8 \mu \mathrm{g} / \mathrm{ml}$ cisplatin

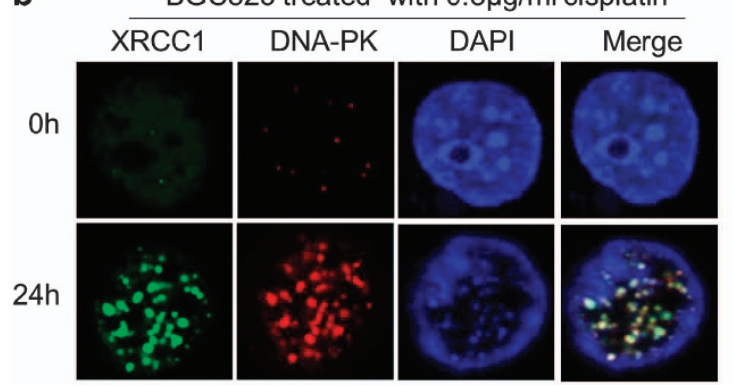

C

BGC823/DDP treated with $10 \mu \mathrm{g} / \mathrm{ml}$ cisplatin

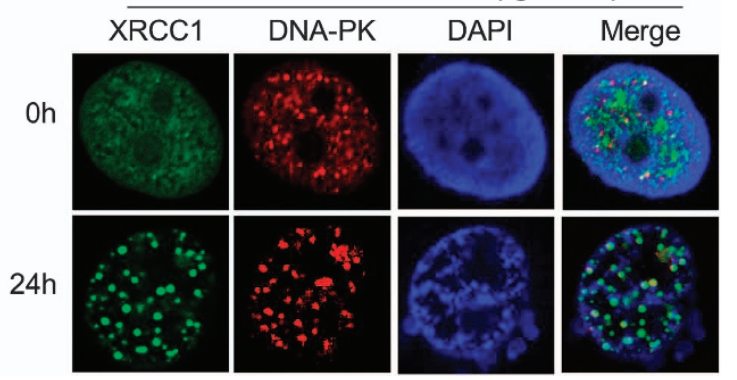

Figure 4 DNA damage and repair proteins are highly expressed in acquired cisplatin-resistant gastric cancer cells. (a) The levels of DNA-PK, XRCC1, P-CHK1, FANCD2, and $\gamma \mathrm{H} 2 \mathrm{AX}$ were determined by western blotting. The BGC823 and BGC823/DDP cells were exposed to cisplatin for $0,1,4,8,12$, and $24 \mathrm{~h}$. (b) The BGC823 cells were exposed to $0.8 \mu \mathrm{g} / \mathrm{ml}$ of cisplatin for $24 \mathrm{~h}$ for XRCC1 and DNA-PK foci staining. (c) The BGC823/DDP cells were exposed to $10 \mu \mathrm{g} / \mathrm{ml}$ of cisplatin for $24 \mathrm{~h}$ for XRCC1 and DNA-PK foci staining

PS-341 inhibited its degradation (Figure 5h). These data indicated that irinotecan enhanced effect of cisplatin on resistant gastric cancer cells via promoting the ubiquitination and degradation of XRCC1.

TXNL1 negatively regulates XRCC1 expression in BGC823/DDP cells and gastric tumor tissues. To explore the mechanism for XRCC1 overexpression in BGC823/DDP cells, we determined if the degradation of XRCC1 was blocked in the cells. When the cells were treated with cycloheximide $(\mathrm{CHX})$, the XRCC1 degradation was found much slower in the BGC823/DDP cells than that in the BGC823 cells (Figures $6 a$ and $b$ ). In addition, the levels of XRCC1 mRNA were also increased up to 2.56-fold in the BGC823/DDP cells compared with the BGC823 cells (Supplementary Figure 5).

To identify potential cisplatin resistance associated target proteins, we used two-dimensional electrophoresis (2-DE) in combination with MALDI-TOF MS to find the differences in proteomics between the BGC823 and BGC823/DDP cells. As a result, about 40 differentially expressed proteins were successfully identified. Our attention was first drawn toward the TXNL1 as it was only detected in BGC823 cells but undetectable in BGC823/DDP cells (Figures $6 \mathrm{c}$ ). To verify this result, western blotting was performed and the results showed that TXNL1 levels were fivefold higher in BGC823 cells than that in BGC823/DDP cells (Figures 6c).

TXNL1 is a two-domain of $32 \mathrm{kDa}$ protein composed of an $\mathrm{N}$-terminal Trx domain and a C-terminal domain that interacts with the $26 \mathrm{~S}$ proteasome. ${ }^{20-22}$ We next addressed the question whether the downregulated TXNL1 expression in BGC823/DDP cells contributes to the degradation of XRCC1 linked to cisplatin resistance? We investigated the role of TXNL1 as an antioxidant molecule in response to oxidative stress in BGC823 cells and BGC823/DDP cells by treatment with another chemotherapy agent arsenic trioxide $\left(\mathrm{As}_{2} \mathrm{O}_{3}\right)$, which is known to induce DNA damage and apoptosis via reactive oxygen species (ROS) production in cancer cells. The mean $\mathrm{IC}_{50}$ value of $\mathrm{As}_{2} \mathrm{O}_{3}$ in $\mathrm{BGC823/DDP}$ cells $(51.30 \mu \mathrm{g} / \mathrm{ml})$ was significantly higher than that of BGC823 cells $(3.73 \mu \mathrm{g} / \mathrm{ml}$; Figure $6 \mathrm{~d})$, and the calculated $\mathrm{RI}$ to $\mathrm{As}_{2} \mathrm{O}_{3}$ was 13.7. Interestingly, TXNL1 was downregulated whereas $\mathrm{XRCC1}$ was upregulated in a dose-dependent manner in BGC823 cells after treatment with $\mathrm{As}_{2} \mathrm{O}_{3}$; in contrast, TXNL1 was upregulated while XRCC1 was downregulated in a dosedependent manner in BGC823/DDP cells after treatment with $\mathrm{As}_{2} \mathrm{O}_{3}$ (Figure 6e). These data suggested that there are a completely negative relationship between TXNL1 and XRCC1 expression, which may have an important role in gastric cancer cells responsive to oxidative stress and contribute to cisplatin resistance. A series of cell culture models were then completed to further confirm this relationship. As shown in Figure 6f, XRCC1 was upregulated 2.9-fold when TXNL1 was knocked down in BGC823 cells without cisplatin treatment or upregulated 2.3-fold with cisplatin treatment. In contrast, XRCC1 was downregulated 2.9-fold upon overexpression of TXNL1 in the BGC823/DDP cells without cisplatin treatment or downregulated 10-fold with cisplatin treatment (Figure 6g). Accordingly, the $\gamma \mathrm{H} 2 \mathrm{AX}$ levels correlated with the XRCC1 expression in the both cell lines (Figures $6 f$ and $g$ ). 

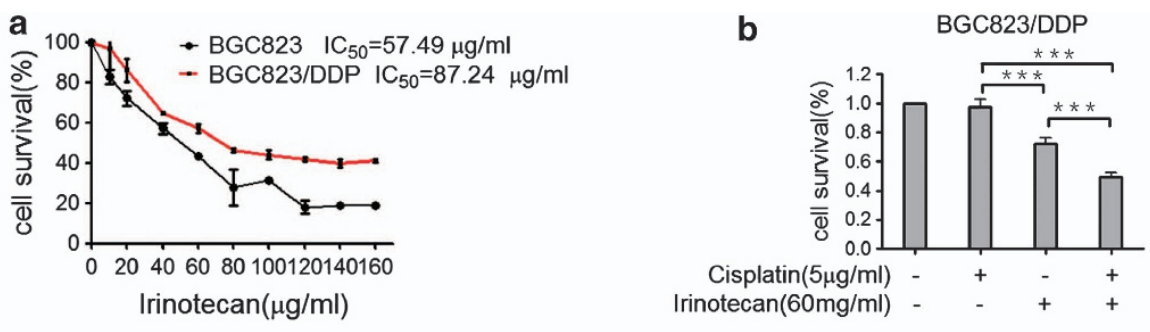

C
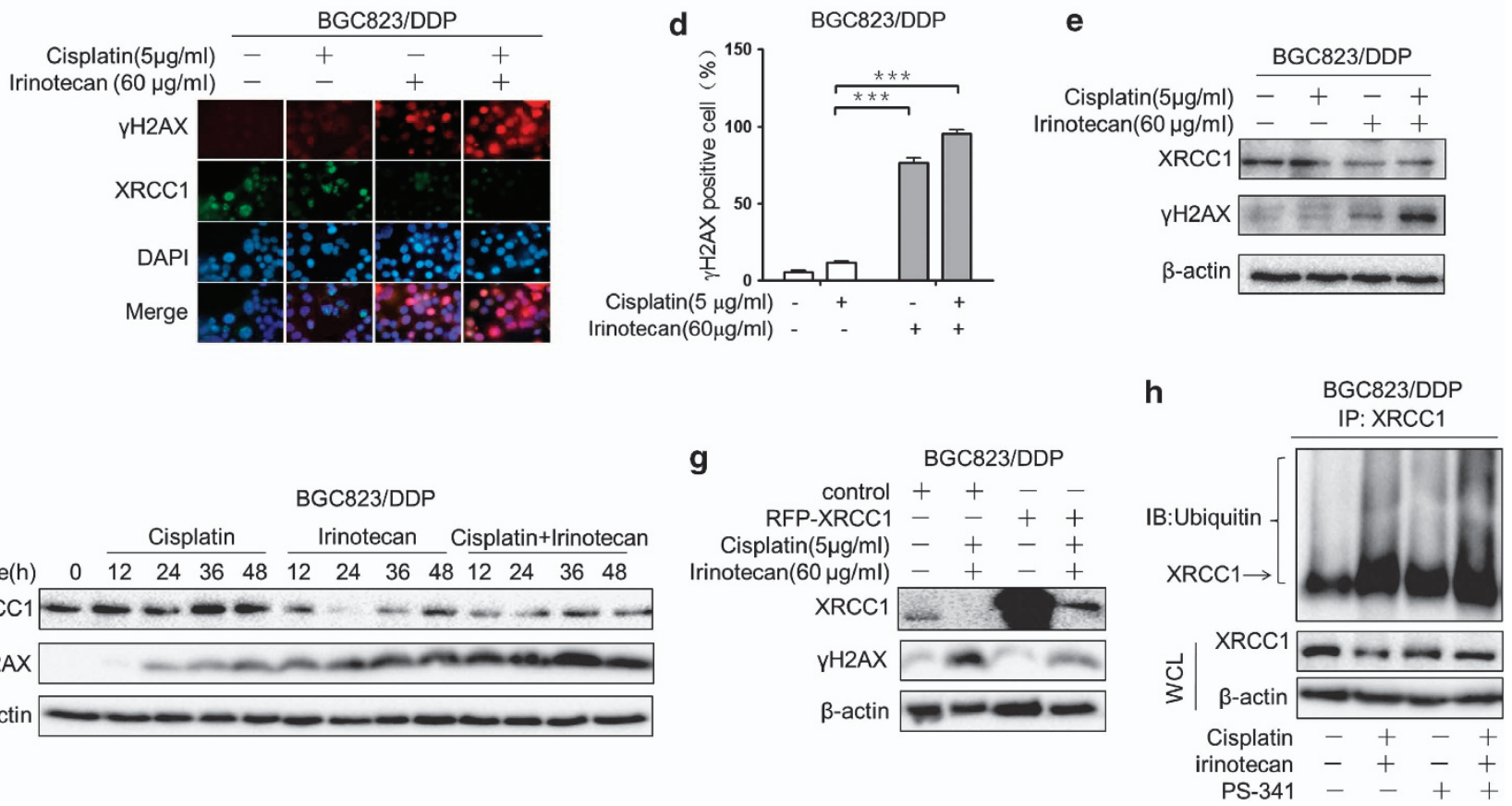

Figure 5 Irinotecan inhibits the expression of XRCC1 and enhances the sensitivity to cisplatin in resistant gastric cancer cells. (a) The viability of BGC823 and BGC823/ DDP cells exposed to irinotecan for $48 \mathrm{~h}$ was determined by CCK-8 assay. (b) The viability of BGC823/DDP cells exposed to $60 \mu \mathrm{g} / \mathrm{ml}$ of irinotecan combined with $5 \mu \mathrm{g} / \mathrm{ml}$ of cisplatin for $48 \mathrm{~h}$ was determined by CCK-8 assay. (c) The BGC823/DDP cells exposed to $60 \mu \mathrm{g} / \mathrm{ml}$ of irinotecan combined with $5 \mu \mathrm{g} / \mathrm{ml}$ of cisplatin for $24 \mathrm{~h}$ were analyzed with $\gamma \mathrm{H} 2 \mathrm{AX}$ staining. (d) Quantification of $\gamma \mathrm{H} 2 \mathrm{AX}$ foci-positive cells of BGC823/DDP cells exposed to $60 \mu \mathrm{g} / \mathrm{ml}$ of irinotecan combined with $5 \mu \mathrm{g} / \mathrm{ml}$ of cisplatin. (e) Western blotting determined the levels of XRCC 1 and $\gamma \mathrm{H} 2 \mathrm{AX}$ in BGC823/DDP cells exposed to $60 \mu \mathrm{g} / \mathrm{ml}$ of irinotecan combined with $5 \mu \mathrm{g} / \mathrm{ml}$ cisplatin for $24 \mathrm{~h}$. (f) Western blotting determined the levels of XRCC 1 and $\gamma$ H2AX in BGC823/DDP cells exposed to $60 \mu \mathrm{g} / \mathrm{ml}$ of irinotecan combined with $5 \mu \mathrm{g} / \mathrm{ml}$ of cisplatin for $0,12,24,24,36$, and $48 \mathrm{~h}$. (g) Western blotting determined the level of XRCC1 and $\gamma \mathrm{H} 2 \mathrm{AX}$ in BGC823/DDP cells transfected with RFP-XRCC1. (h) The BGC823/DDP cells treated with $60 \mu \mathrm{g} / \mathrm{ml}$ of irinotecan combined with $5 \mu \mathrm{g} / \mathrm{ml}$ of cisplatin for $24 \mathrm{~h}$ then treated with $50 \mu \mathrm{M}$ PS-341 for $6 \mathrm{~h}$. Western blotting was performed to confirm the levels of XRCC 1 and immunoprecipitation was used to show the ubiquitination of XRCC1. Results are representative of at least three experiments and shown as the mean \pm S.D. ${ }^{* \star *} P<0.001$

Furthermore, immunofluorescence staining also verified these results and showing that the reduced XRCC1 expression was observed when BGC823/DDP cells were transfected with Flag-TXNL1 plasmid (Figure 6h). Moreover, it was shown that irinotecan induced the TXNL1 expression and simultaneously downregulated XRCC1 in BGC823/DDP cells (Figure 6i).

To further determine the potential mechanism by which the expression of XRCC1 is negatively regulated by TXNL1, BGC823/DDP cells were transfected with flag-TXNL1 or control plasmid and then treated with $\mathrm{CHX}$. We found that the overexpression of TXNL1 promoted the degradation of XRCC1 (Figures 6j and k). Once the Flag-TXNL1-transfected cells were treated with proteasome inhibitors MG132 at $10 \mu \mathrm{M}$ or PS-341 at $50 \mu \mathrm{M}$ for $6 \mathrm{~h}$, the XRCC1 expression was effectively rescued. Concurrently, ubiquitinated XRCC1 increased because of MG132 or PS-341 inhibiting its degradation. Taken together, the data showed that the mechanism of TXNL1-mediated XRCC1 degradation was due to enhanced ubiquitination of XRCC1 (Figure 6l).

To further determine the relationship between TXNL1 and XRCC1 in human gastric tumor tissues, a tissue microarray containing 103 cases of eligible primary tumor samples showed a statistically significant negative correlation between TXNL1 and XRCC1 expressions (Table 1, Figure 7a, $P<0.001)$. An opposite expression pattern between TXNL1 and XRCC1 in the same location was also shown, and TXNL1 staining was localized in the cytoplasm and nuclei, whereas XRCC1 was exclusively expressed only in the nuclei (Figure 7b). Finally, the opposite expression pattern of TXNL1 and XRCC1 proteins were also confirmed in 12 paired gastric tumor tissues (Figure 7c).

Role of transmembrane drug transport and detoxification. Drug resistance in cancer cells occurs via multiple complicated mechanisms. The DNA repair capacity is important but 
a
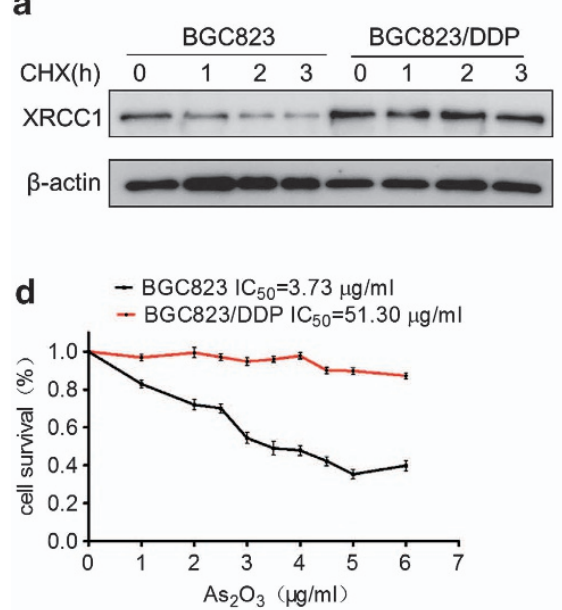

$b_{3}$

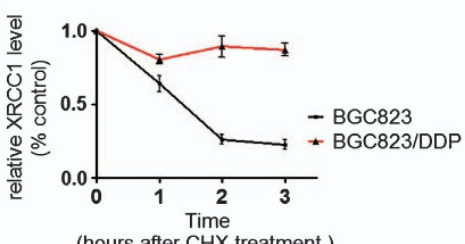

(hours after $\mathrm{CHX}$ treatment)

e

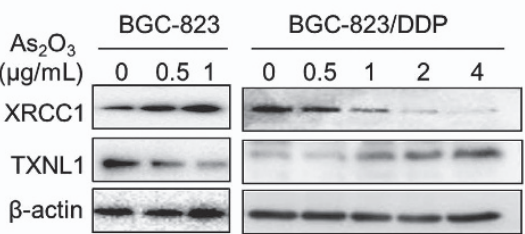

C
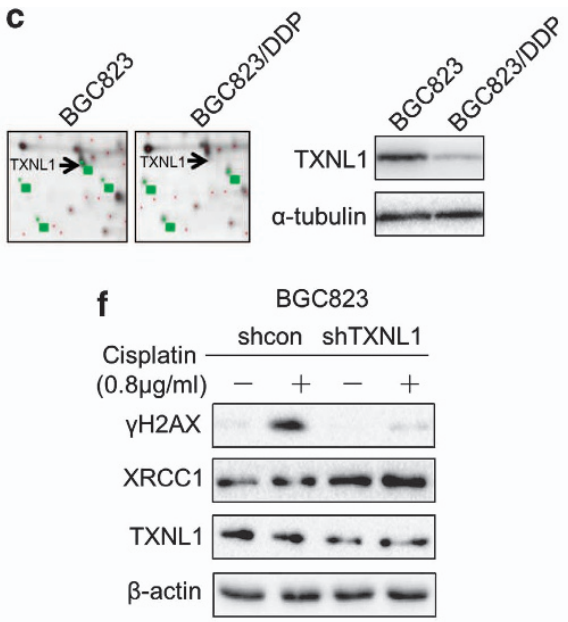

g

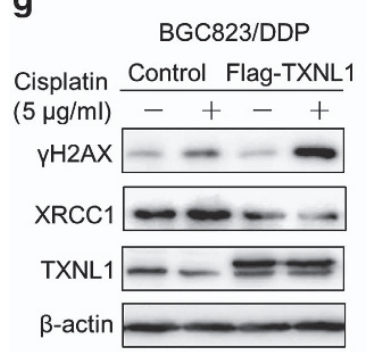

h
BGC823/DDP

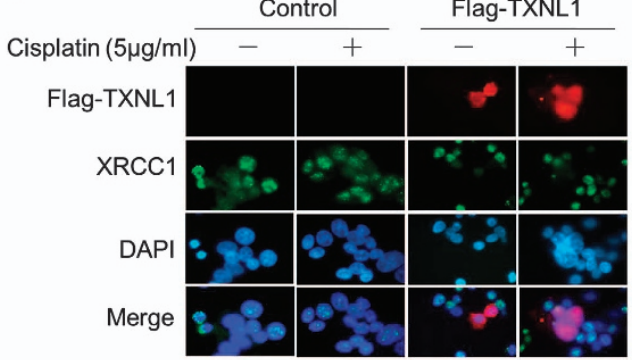

i

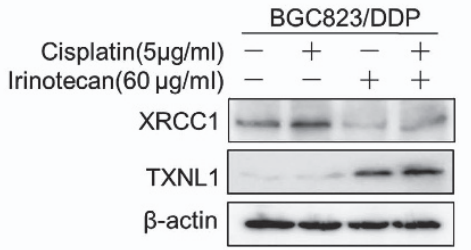

I

BGC823/DDP

IP: XRCC1

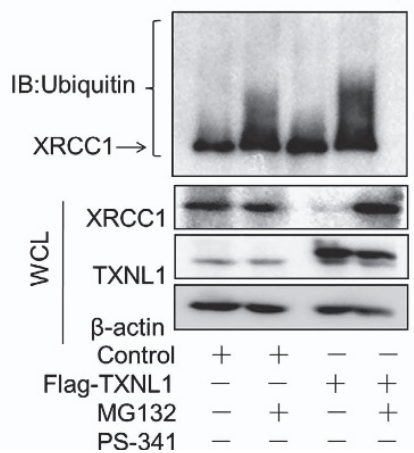

IP: XRCC1

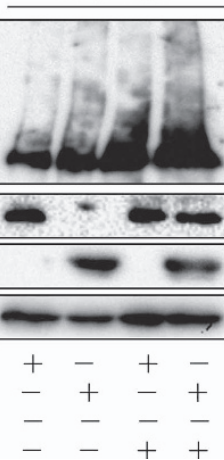

Figure 6 The TXNL1 downregulates XRCC1 through the Ub-proteasome pathway. (a) The protein stability of XRCC1 in BGC823 or BGC823/DDP cells was assessed by western blotting after treatment with $50 \mu \mathrm{g} / \mathrm{ml}$ of CHX for the indicated times. (b) Quantification of XRCC1 protein level of BGC823/DDP cells after treatment with $50 \mu \mathrm{g} / \mathrm{ml}$ of $\mathrm{CHX}$ for the indicated times. (c) The expression of TXNL1 was determined by 2-DE-MS and western blotting. The arrows showed the location of TXNL1. (d) The viability of BGC823 and BGC823/DDP cells exposed to $\mathrm{As}_{2} \mathrm{O}_{3}$ for $48 \mathrm{~h}$ was determined by CCK-8 assay. (e) The BGC823 cells and BGC823/DDP cells exposed to $\mathrm{As}_{2} \mathrm{O}_{3}$ for $24 \mathrm{~h}$ were analyzed by western blotting to determine the level of TXNL1 and XRCC1. (f) BGC823 cells transfected with TXNL1 shRNA for $48 \mathrm{~h}$ followed by exposure to $0.8 \mu \mathrm{g} / \mathrm{ml}$ of cisplatin for $24 \mathrm{~h}$ to give western blotting to determine the level of TXNL1, XRCC1, and $\gamma \mathrm{H} 2 \mathrm{AX}$. (g) The BGC823/DDP cells transfected with flag-TXNL1 for $48 \mathrm{~h}$ followed by exposure to $5 \mu \mathrm{g} / \mathrm{ml}$ of cisplatin for $24 \mathrm{~h}$ for western blotting to determine the level of TXNL1, XRCC1, and $\gamma$ H2AX. (h) The BGC823/DDP cells transfected with Flag-TXNL1 for $48 \mathrm{~h}$ followed by exposure to $5 \mu \mathrm{g} / \mathrm{ml}$ of cisplatin for $24 \mathrm{~h}$ were analyzed by XRCC1 foci staining. (i) The BGC823/DDP cells exposed to $60 \mu \mathrm{g} / \mathrm{ml}$ of irinotecan combined with $5 \mu \mathrm{g} / \mathrm{ml}$ of cisplatin for $24 \mathrm{~h}$ were analyzed by western blotting to determine the level of XRCC1 and TXNL1. (j) The protein stability of XRCC1 in BGC823/DDP cells transfected with flag-TXNL1 for $48 \mathrm{~h}$ assessed by western blotting analysis after treatment with $50 \mu \mathrm{g} / \mathrm{ml}$ of CHX at the indicated times. (k) Quantification of XRCC1 protein level of BGC823/DDP cells transfected with flag-TXNL1 after treatment with $50 \mu \mathrm{g} / \mathrm{ml}$ of $\mathrm{CHX}$ at the indicated times. (I) The BGC823/DDP cells transfected with flag-TXNL1 for $48 \mathrm{~h}$ were treated with $10 \mu \mathrm{M}$ of MG132 or $50 \mu \mathrm{M}$ of PS-341 for $6 \mathrm{~h}$. Western blotting was performed to confirm the levels of XRCC1 and immunoprecipitation was used to show the ubiquitination of XRCC1

transmembrane drug transport and detoxification may be involved in as well. Here we compared the expression of a membrane cisplatin uptake protein, copper transporter 1 (CTR1) and multidrug resistance-associated protein
2 (MRP2), a cisplatin efflux protein where the CTR1 was significantly decreased while the MRP2 was increased in the BGC823/DDP versus BGC823 cells, respectively (Supplementary Figure 6a). Corresponding to these results, 
atomic absorbance spectrometry measurements were used and indicated that the intracellular platinum content was lower in BGC823/DDP cells than in BGC823 cells after treatment with $10 \mu \mathrm{g} / \mathrm{ml}$ of cisplatin for $2 \mathrm{~h}$ (Supplementary Figure $6 \mathrm{~b}$ ). In addition, the glutathione (GSH) content, which is known to detoxify cisplatin, was found higher in BGC823/DDP cells than that in BGC823 cells (Supplementary Figure 6c). Taken together, we deducted that cisplatin resistance in the tested gastric cancer cells was mediated by enhanced DNA repair capacity but that reduced intracellular cisplatin concentration because of altered transmembrane transport and detoxification also may have a role.

\section{Discussion}

Increasing evidence is mounting on the role of XRCC1 in cisplatin resistance. In this study, we have provided new evidences supporting that cisplatin resistance developed in the gastric cancer cells is at least in part because of the XRCC1 overexpression as a result of inhibition of TXNL1, presumably leading to a super strong capacity of DNA repair. At the same time, we also revealed a new mechanism by which irinotecan has a role in inducing TXNL1 expression

Table 1 The expression of TXNL1 and XRCC1 in human gastric cancer tissue microarray

\begin{tabular}{lccc}
\hline \multirow{2}{*}{ TXNL1 } & \multicolumn{2}{c}{ XRCC1 } & P-value \\
\cline { 2 - 4 } & Low & High & \\
\hline Low & $21(46.67 \%)$ & $24(53.33 \%)$ & 0.000 \\
High & $24(96.00 \%)$ & $1(4.00 \%)$ & \\
\hline
\end{tabular}

to further trigger ubiquitin (Ub)-proteasome-mediated XRCC1 degradation in cisplatin-resistant gastric cancer cells.

Cisplatin is one of the most potent chemotherapeutics widely used in cancer chemotherapy. Cisplatin combined with other agents like fluorouracil, capecitabine, and epirubicine is routinely used to treat advanced gastric cancer. ${ }^{23}$ The anticancer mechanism of cisplatin is attributed to the platinum-DNA adducts induced cell death. Cancer cells could develop several mechanisms to anti-cisplatin-induced cell death, leading to cisplatin resistance. Here, we determined both pre-target and on-target resistance mechanisms such as cisplatin transport, accumulation, detoxification, and DNA repair capacity, as described in other models for cisplatin resistance. ${ }^{5}$ Our results indicated that the development of cisplatin resistance in gastric cancer cells might be a synergetic effect associated with less accumulation of intracellular cisplatin by reduced expression of CTR1 and increased MRP2, and enhanced ability of cisplatin detoxification by GSH.

Early cisplatin-induced DNA damage is intrastrand and interstrand crosslinks and adducts, resulting in stalled replication forks, conferring DSB. ${ }^{24}$ DNA repair pathways including NER, HR, NHEJ could contribute to cisplatin resistance, ${ }^{25-29}$ forming a highly complex, interacting defense mechanism against the genotoxic damage induced by cisplatin. ${ }^{30}$ However, the mechanisms are currently not elucidated enough to confer clinical value, and thus it is of high importance to reveal novel molecules or pathways involved in cisplatin resistance and how they are regulated.

We have previously demonstrated the prognostic and predictive values of XRCC1 expression in patients with gastric cancer. ${ }^{16}$ We have shown significantly lower expression of

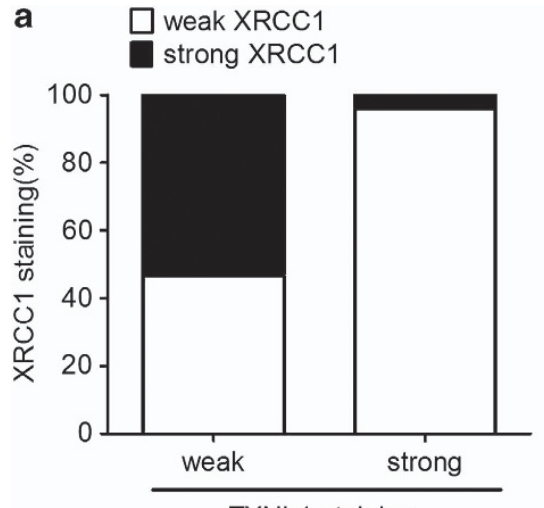

TXNL1 staining b TXNL1 weak TXNL1 strong

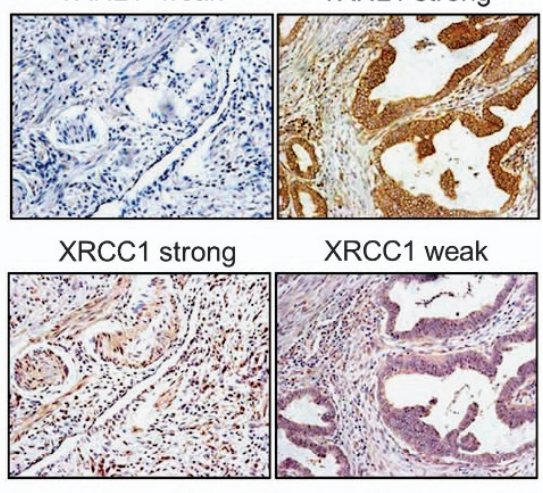

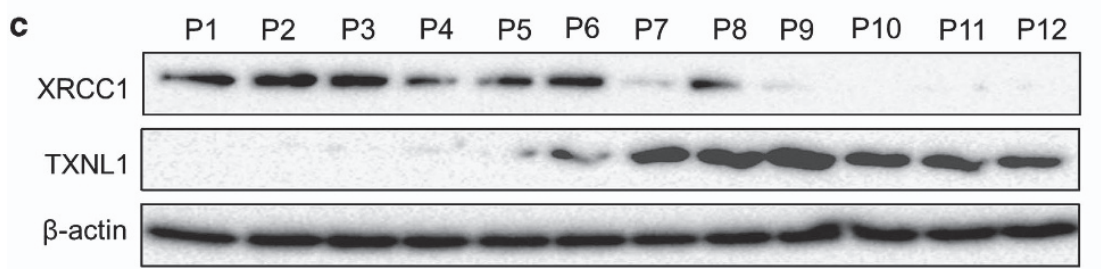

Figure 7 Expression of TXNL1 and XRCC1 in human gastric cancer tissues. (a) Histogram represents the negative expression of TXNL1 and XRCC1 in tissue microarray. (b) Representative images of immunohistochemical staining of tissues with TXNL1 and XRCC1 antibody, original magnification $\times 200$. (c) TXNL1 and XRCC1 protein levels in 12 human gastric cancer tissues were analyzed by western blotting. P, patient 
XRCC1 proteins in gastric cancer tissues versus paired normal tissues, indicating a potentially important role of this gene in gastric carcinogenesis and cancer progression. Our results also indicate that platinum-based chemotherapy significantly increased overall survival in the gastric cancer patients with low XRCC1 expression, but had no obvious effect on those with high expression. ${ }^{16}$ In this study, we found a significantly higher level of XRCC1 expression in the cisplatin-resistant BGC823/DDP cells, as well as in the intrinsic cisplatin-resistant cell line MGC803. Knockdown of XRCC1 in the cisplatin-resistant cells resulted in higher sensitivity to cisplatin, increased $\gamma \mathrm{H} 2 \mathrm{AX}$ levels, and apoptosis while, on the contrary, overexpression of XRCC1 in cisplatinsensitive cells resulted in less cytotoxicity, reduced $\gamma \mathrm{H} 2 \mathrm{AX}$ levels, and apoptosis when treated with cisplatin. These results indicated that $\mathrm{XRCC} 1$ has a key role in cisplatin resistance of gastric cancer. Cisplatin is known to induce DSB that are repaired by the HR and NHEJ mechanisms. Our results showed that $\mathrm{XRCC} 1$ also had an independent role in this process, indicating that a more rapid damage response and more effective DNA repair of cisplatin-induced damage developed in these cells. It has been shown that XRCC1 interacts with DNA-PK in response to IR-induced DSB, and that PARP1-XRCC1 DSB repair in mouse round spermatids has an important role of XRCC1 in NHEJ. ${ }^{15,31}$ In this study, we observed the colocalization between XRCC1 and DNA-PK in cells treated with cisplatin, indicating that XRCC1 may join the DSB repair process triggered by cisplatin through the NHEJ pathway. Therefore, XRCC1 may not only independently contribute to cisplatin resistance, but also function as a crosstalk molecule to coordinate various DNA repair pathways of the network.

The XRCC1 levels can be precisely controlled by post-translational modifications such as phosphorylation and ubiquitination of the cells. ${ }^{32}$ The role of the Ub-proteasome pathway of controlling XRCC1 has been highlighted by others as well. ${ }^{33,34}$ In this study, we identified that TXNL1, a protein almost completely lost in the resistant cells, negatively regulated $\mathrm{XRCC} 1$ expression. We found that $\mathrm{XRCC} 1$ was regulated by TXNL1 through the proteasome pathway, suggesting an important role of C-terminal domain of TXNL1 for XRCC1 degradation. The N-terminal Trx domain of TXNL1 is involved in the regulation of the redox balance in the cells. Our results indicated that ROS inhibited TXNL1 and increased XRCC1 expression in cisplatin-sensitive BGC823 cells, suggesting that an effective response mechanism to DNA damage agent cisplatin exists in these cells. However, a totally inverse relationship was observed in the BGC823/DDP, indicating that a dysfunctional redox response network is established in the acquired cisplatin-resistant gastric cancer cells.

Irinotecan is a camptothecin analog approved as first-line chemotherapy of advanced colorectal cancer and second-line therapy of advanced gastric cancer. Although a connection between the XRCC1 pathway and the repair of DNA damage induced by Top-I cleavage complexes has been reported, ${ }^{35}$ the exact molecular mechanisms are unknown. In this study, we provide evidence that irinotecan effectively inhibits the XRCC1 expression through TXNL1-mediated Ub-proteasome pathway. Moreover, a synergistic effect of irinotecan combined with cisplatin-triggered cell death in cisplatinresistant cells. Although cisplatin and irinotecan have previously shown synergism in preclinical models, ${ }^{36}$ the mechanism discovered in this study is novel. Clinical trials in patients with gastric cancer treated with combination of these two agents have demonstrated a complete pathological response in $28 \%$ of patients ${ }^{37}$ and the clinical efficacy has also been observed in patients with metastatic gastric cancer ${ }^{38}$ or lung cancer. $^{39}$

Taken together, we report for the first time that TXNL1regulated XRCC1 degradation has an independent role in gastric cancer resistance to cisplatin. Irinotecan has a synergistic effect with cisplatin in cisplatin-resistant gastric cancer cells through suppression of XRCC1 (Figure 8). We therefore speculate that XRCC1 and TXNL1 are potential drug targets and resistance biomarkers for adjuvant chemotherapy with platinum-based regimen in gastric cancer. Further evaluation of these biomarkers in prospective clinical studies is warranted.

\section{Materials and Methods}

Cell lines and culture. Human gastric cancer cell lines BGC823 and MGC803 were purchased from the Type Culture Collection of the Chinese Academy of Sciences (Shanghai, China). XRCC1-deficient EM9 cells were kindly provided by Professor Marit Otterlei (Norwegian University of Science and Technology, Trondheim, Norway). All the cells were cultured in RPMI 1640 medium supplemented with $10 \%$ of fetal bovine serum, $100 \mathrm{U} / \mathrm{ml}$ of penicillin, and $100 \mu \mathrm{g} / \mathrm{ml}$ of streptomycin (Life Technologies/Gibco, Grand Island, NY, USA). The cells were grown at $37^{\circ} \mathrm{C}$ in a humidified incubator with $5 \% \mathrm{CO}_{2}$. Cisplatin was obtained from Sigma-Aldrich (St. Louis, MO, USA). The cisplatin-resistant BGC823/DDP cells were developed from the parental BGC823 cells that were subjected to persistent gradient exposure to cisplatin for about 12 month, through increasing cisplatin concentration from $0.05 \mu \mathrm{g} / \mathrm{ml}$ until the cells acquired resistance to $1 \mu \mathrm{g} / \mathrm{ml}$. Before each experiment, BGC823/DDP cells were cultured in drug-free RPMl 1640 medium for 2 weeks.

Plasmids and transfection. The GFP-XRCC1 plasmid was constructed from the RFP-XRCC1 plasmid that has been described previously. ${ }^{40}$ The XRCC1 siRNA (5'-GGAATGGGATCCCAGCTTTGA- $\left.3^{\prime}\right)$ and its control siRNA (5'-GTTCTC CGAACGTGTCACGT-3'); the TXNL1 siRNA (5'-CGTCTTTCTTCACTTGGTTGAA GAG- $3^{\prime}$ ) and its control siRNA ( $5^{\prime}$-GTTCTCCGAACGTGTCACGT- $3^{\prime}$ ) expression cassettes were subcloned into the vector pGPU6/GFP/Neo to produce XRCC1 shRNA, TXNL1shRNA, and control shRNA plasmids, respectively. To confirm the role of plasmid expressed siRNA, another nude small interfering RNA (siRNA) specific for XRCC1 (5'-GGUCCUUCUAUAUCUGUAAdTdT-3') and nonspecific control siRNA was synthesized (Ribobio, Guangzhou, China). The flag-TXNL1 plasmid was kindly provided by Professor Jean Gruenberg (University of Geneva, Geneva, Switzerland). The plasmid DNA or siRNA was transfected into cells with Lipofectamine 2000 (Life Technologies, Grand Island, NY, USA) according to manufacturer's instructions.

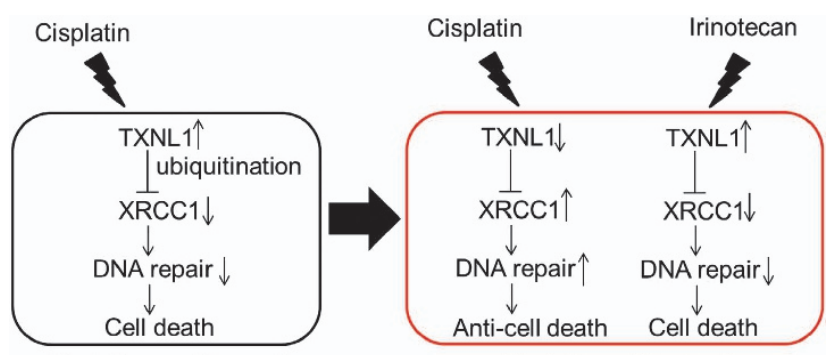

Cisplatin sensitive cell

Cisplatin resistant cell

Figure 8 Diagram illustrates the proposed molecular signaling of cisplatin resistance in human gastric cancer based on current results 
Cytotoxicity assay. One day before treatment, BGC823, BGC823/DDP, or MGC803 cells were plated at a density of 5000 cells per well in 96 -well plates. The cells were treated with various concentrations of cisplatin $(0.05-20 \mu \mathrm{g} / \mathrm{ml})$ and $/$ or irinotecan (Sigma-Aldrich; $10-160 \mu \mathrm{g} / \mathrm{ml}$ ). After $48 \mathrm{~h}$, the cell viability was determined using Cell Counting Kit-8 (CCK-8) according to the manufacturer's instructions (Dojindo, Kumamoto, Japan). The cell variable curves were plotted and the $\mathrm{IC}_{50}$ values were computed through non-linear regression analysis by Graph Pad Prism software (La Jolla, CA, USA). The cell survival rates were expressed as mean \pm S.D. from at least three independent experiments.

Clonogenic assay. After $48 \mathrm{~h}$, the transfected BGC823, BGC823/DDP, or EM9 cells were treated with cisplatin at indicated concentrations for $2 \mathrm{~h}$; and the cells were then trypsinized, seeded in six-well plates (300 cells per well) and further cultured for 2 weeks to BGC823 and EM9 cells or 3 weeks to BGC823/ DDP cells, respectively. For scoring colonies, the cells were fixed in $1 \mathrm{ml}$ of methanol for $15 \mathrm{~min}$ and stained with Giemsa for $10 \mathrm{~min}$. The numbers of cloning were expressed as mean \pm S.D. from at least three independent experiments.

Atomic absorbance spectrometry. To measure the intracellular concentrations of platinum, the cells were treated with cisplatin at $10 \mu \mathrm{g} / \mathrm{ml}$ for $2 \mathrm{~h}$ when the cells reached at $80-90 \%$ confluence. Cells were then washed and harvested after cisplatin treatment. Total platinum per milligram of cells was determined by Analytik Jena AG contrAA 700 Atomic absorbance spectrometer (Jena, Freistaat Thüringen, Germany) at wavelength of $265 \mathrm{~nm}$.

GSH measurement. Total GSH per milligram of cells was measured using the GSH and GSSG Assay Kit (Beyotime, Jiangsu, China) according to the manufacturer's instructions.

Apoptosis assay. Apoptosis was determined using the TUNEL apoptotic cell detection kit (Roche, Basel, Switzerland), according to the manufacturer's instructions. The percentages of apoptotic cells were counted from at least 1000 cells.

Western blotting. Western blot analyses were performed as previously described. ${ }^{41}$ The antibodies used were as follows: monoclonal anti- $\alpha$-tubulin, anti$\beta$-actin (1: 2000, Beyotime); monoclonal anti-XRCC1, anti-CTR1, anti-MRP2, antiDAN-PK, anti-FANCD2 (1:2000, Epitomics, Burlingame, CA, USA); polyclonal anti-TXNL1 (1:2000, Proteintech, Chicago, IL, USA); anti- $\gamma$ H2AX $(1: 2000$, Upstate, New York, NY, USA); monoclonal anti-PARP (1:1000, Cell Signaling Technology, Danvers, MA, USA); and monoclonal anti-Ub (1:500, Santa Cruz, Dallas, TX, USA). CHX and MG132 were purchased from Sigma-Aldrich.

RNA extraction and reverse transcription-PCR. Total RNA was extracted from the cells using the Trizol reagent (Gibco, Gaithersburg, MD, USA) and quantified by UV spectrometry. Approximately $1 \mu \mathrm{g}$ of RNA was used for the reverse transcription reaction with OligodT (18T) (Life Technologies). The cDNA was amplified with the following primers: $5^{\prime}$-CATGTGGGCCATGAGGTCCACCAC-3' (forward) and $5^{\prime}$-GGGAAGCTCACTGGCATGGCCTTCC-3' (reverse) for GAPDH; 5'-ACTGCTGGAACCTGGCCCTGC-3' (forward) and 5'-GCAAACCCCGAGGA GAAGGCA-3' (reverse) for XRCC1. The following thermal cycling conditions were used: denaturation at $94^{\circ} \mathrm{C}$ for $5 \mathrm{~min}$ followed by 36 cycles of denaturation at $94^{\circ} \mathrm{C}$ for $35 \mathrm{~s}$, annealing at $56^{\circ} \mathrm{C}$ for $30 \mathrm{~s}$, and extension at $72{ }^{\circ} \mathrm{C}$ for $35 \mathrm{~s}$.

Indirect immunofluorescence microscopy. Indirect immunofluorescence staining was performed as previously reported. ${ }^{42}$ The cells were incubated with anti- $\gamma \mathrm{H} 2 \mathrm{AX}$ mouse monoclonal antibody, anti-XRCC1 rabbit monoclonal antibody, anti-DNA-PK rabbit monoclonal antibody, and anti-flag mouse monoclonal antibody (Beyotime) at a 1:200 dilution, respectively. The confocal images of cells were sequentially acquired with Zeiss AIM software on a Zeiss LSM 510 confocal microscope system (Jena).

Immunoprecipitation: Immunoprecipitations were performed as previously described. ${ }^{40}$ Briefly, the cells were harvested and lyzed in cold lysis buffer $(50 \mathrm{mM}$ Tris (pH 7.4), $150 \mathrm{mM} \mathrm{NaCl}, 1 \mathrm{mM}$ EDTA, $0.5 \%$ (v/v) NP-40, $10 \%$ (v/v) glycerol,1 mM PMSF). The cell extracts were centrifuged at $12000 \times g$ at $4{ }^{\circ} \mathrm{C}$ for $15 \mathrm{~min}$, and the supernatant was then incubated with protein $\mathrm{A} / \mathrm{G}$ agarose beads (Santa Cruz) as a pre-treatment. Precleared lysates were then incubated with
anti-XRCC1 antibody or control IgG for $1 \mathrm{~h}$, and then incubated overnight with protein $A / G$ agarose beads. The beads were collected by centrifugation, washed three times with the lysis buffer and resuspended in $1 \times$ SDS loading buffer. The immunoprecipitates were eluted from the beads by incubation at $95^{\circ} \mathrm{C}$ for $5 \mathrm{~min}$. The eluted proteins were separated by SDS-PAGE and western blotting was subsequently performed with Ub antibodies.

Two-dimensional electrophoresis and mass spectrometry. 2-DE and mass spectrometry (MS) were performed as previously described. ${ }^{43}$ Briefly, $1.5 \mathrm{mg}$ of protein extracts of BGC823 cells or BGC823/DDP cells were loaded for 2-DE, respectively. The gels were fixed for silver staining. Then the stained 2-DE gels were scanned with an Image Scanner (Amersham Biosciences, Little Chalfont, UK) and analyzed with PD Quest 2-DE software (Hercules, CA, USA) according to the manufacturer's instructions. The following criteria for differential protein expression were used: spot intensity $\geq 2$-fold increase or decrease in BGC823/DDP cells compared with BGC823 cells. The MALDI-TOF-MS experiments were carried out with the Tof-SpecE (Bruker Daltonics, Bremen, Germany) equipment. The proteins were identified by search in Swiss-Prot and NCBI non-redundant databases using the ProFound software (The Rockefeller University, New York, NY, USA).

Tissue microarray and evaluation immunohistochemistry. The tissue microarray included 103 cases who underwent radical gastrectomy at Nantong Cancer Hospital (Nantong, China) from 1 May 1990 to 1 June 1995 was studied before. ${ }^{16}$ The immunohistochemistry staining was also as described. Staining of TXNL1 and XRCC1 in the tissue was scored independently by two pathologists blinded to the clinical data, by applying a semi quantitative immunoreactivity score (IRS) as reported elsewhere. ${ }^{44}$ Category A documented the intensity of immunostaining as $0-3$ (0, negative; 1 , weak; 2 , moderate; 3 , strong). Category $B$ documented the percentage of immunoreactive cells as one $(0-25 \%)$, two $(26-50 \%)$, three $(51-75 \%)$, and four $(76-100 \%)$. Multiplication of category $A$ and $B$ resulted in an IRS ranging from 0 to 12 for each tissue.

Statistical analysis. Data are expressed as the mean \pm S.D. The statistical significance of the differences between the cell lines was determined by the parametric unpaired Student's $t$-test. The Two-tailed Fisher's exact test was used to analyze the correlation between the TXNL1 and XRCC1 levels. Differences were considered significant when $P<0.05$.

\section{Conflict of Interest}

The authors declare no conflict of interest.

Acknowledgements. We thank Professor Jean Gruenberg in University of Geneva, Geneva, Switzerland, for providing flag-TXNL1 plasmid and Professor Marit Otterlei of the Norwegian University of Science and Technology, Trondheim, Norway, for providing EM9 cells. This study was supported in part by the Priority Academic Program Development (PAPD) of Jiangsu Higher Education Institutions; the National Natural Science Foundation of China (grant number 81161120537 , 30930080, 91229125, 81001231, and 81370078); and the Natural Science Foundation of Jiangsu Higher Education Institutions (13KJA330001).

1. Kelley JR, Duggan JM. Gastric cancer epidemiology and risk factors. J Clin Epidemiol 2003; 56: 1-9.

2. Kamangar F, Dores GM, Anderson WF. Patterns of cancer incidence, mortality, and prevalence across five continents: defining priorities to reduce cancer disparities in different geographic regions of the world. J Clin Oncol 2006; 24: 2137-2150.

3. Paoletti X, Oba K, Burzykowski T, Michiels S, Ohashi Y, Pignon JP et al. Benefit of adjuvant chemotherapy for resectable gastric cancer: a meta-analysis. JAMA 2010; 303: 1729-1737.

4. Bang YJ, Kim YW, Yang HK, Chung HC, Park YK, Lee KH et al. Adjuvant capecitabine and oxaliplatin for gastric cancer after D2 gastrectomy (CLASSIC): a phase 3 open-label, randomised controlled trial. Lancet 2012; 379: 315-321.

5. Galluzzi L, Senovilla L, Vitale I, Michels J, Martins I, Kepp 0 et al. Molecular mechanisms of cisplatin resistance. Oncogene 2012; 31: 1869-1883.

6. Rabik CA, Dolan ME. Molecular mechanisms of resistance and toxicity associated with platinating agents. Cancer Treat Rev 2007; 33: 9-23. 
7. Lee J, Lim DH, Kim S, Park SH, Park JO, Park YS et al. Phase III trial comparing capecitabine plus cisplatin versus capecitabine plus cisplatin with concurrent capecitabine radiotherapy in completely resected gastric cancer with D2 lymph node dissection: the ARTIST trial. J Clin Oncol 2012; 30: 268-273.

8. Galanski M. Recent developments in the field of anticancer platinum complexes. Recent Pat Anticancer Drug Discov 2006; 1: 285-295.

9. Lebwohl D, Canetta R. Clinical development of platinum complexes in cancer therapy: an historical perspective and an update. Eur J Cancer 1998; 34: 1522-1534.

10. Azzoli CG, Temin S, Aliff T, Baker SJ, Brahmer J, Johnson DH et al. 2011Focused update of 2009 American Society of Clinical Oncology Clinical Practice Guideline update on chemotherapy for stage IV non-small-cell lung cancer. J Clin Oncol 2011; 29: 3825-3831.

11. Vogelzang NJ, Rusthoven JJ, Symanowski J, Denham C, Kaukel E, Ruffie P et al. Phase III study of pemetrexed in combination with cisplatin versus cisplatin alone in patients with malignant pleural mesothelioma. J Clin Oncol 2003; 21: 2636-2644.

12. Kartalou M, Essigmann JM. Recognition of cisplatin adducts by cellular proteins. Mutat Res 2001; 478: 1-21.

13. Myint WK, $\mathrm{Ng} \mathrm{C}$, Raaphorst GP. Examining the non-homologous repair process following cisplatin and radiation treatments. Int J Radiat Biol 2002; 78: 417-424.

14. Moser J, Kool H, Giakzidis I, Caldecott K, Mullenders LH, Fousteri MI. Sealing of chromosomal DNA nicks during nucleotide excision repair requires XRCC1 and DNA ligase III alpha in a cell-cycle-specific manner. Mol Cell 2007; 27: 311-323.

15. Levy N, Martz A, Bresson A, Spenlehauer C, de Murcia G, Menissier-de MJ. XRCC1 is phosphorylated by DNA-dependent protein kinase in response to DNA damage. Nucleic Acids Res 2006; 34: 32-41.

16. Wang S, Wu X, Chen Y, Zhang J, Ding J, Zhou Y et al. Prognostic and predictive role of JWA and XRCC1 expressions in gastric cancer. Clin Cancer Res 2012; 18: 2987-2996.

17. Siddiqui-Jain A, Bliesath J, Macalino D, Omori M, Huser N, Streiner N et al. CK2 inhibitor CX-4945 suppresses DNA repair response triggered by DNA-targeted anticancer drugs and augments efficacy: mechanistic rationale for drug combination therapy. Mol Cancer Ther 2012; 11: 994-1005.

18. Kudo K, Gavin E, Das S, Amable L, Shevde LA, Reed E. Inhibition of Gli1 results in altered c-Jun activation, inhibition of cisplatin-induced upregulation of ERCC1, XPD and XRCC1, and inhibition of platinum-DNA adduct repair. Oncogene 2012; 31: 4718-4724.

19. Goto A, Sukawa $Y$, Igarashi H, Onodera K, Aoki $Y$, Suzuki K et al. Irinotecan as the key chemotherapeutic agent in second-line treatment of metastatic gastric cancer after failure of first-line S-1 or S-1/CDDP therapy. Gan To Kagaku Ryoho 2011; 38: 1461-1466.

20. Jimenez A, Pelto-Huikko M, Gustafsson JA, Miranda-Vizuete A. Characterization of human thioredoxin-like-1: potential involvement in the cellular response against glucose deprivation. FEBS Lett 2006; 580: 960-967.

21. Felberbaum-Corti M, Morel E, Cavalli V, Vilbois F, Gruenberg J. The redox sensor TXNL1 plays a regulatory role in fluid phase endocytosis. PLoS One 2007; 2: e1144.

22. Andersen KM, Madsen L, Prag S, Johnsen AH, Semple CA, Hendil KB et al. Thioredoxin Txnl1/TRP32 is a redox-active cofactor of the $26 \mathrm{~S}$ proteasome. J Biol Chem 2009; 284: 15246-15254.

23. Kanagavel D, Pokataev IA, Fedyanin MY, Tryakin AA, Bazin IS, Narimanov MN et al. A prognostic model in patients treated for metastatic gastric cancer with second-line chemotherapy. Ann Oncol 2010; 21: 1779-1785.

24. Garcia SD, Aguado L, Montes BM, Comendador MA, Blanco GE, Sanz-Medel A et al. Relationships between cisplatin-induced adducts and DNA strand-breaks, mutation and recombination in vivo in somatic cells of Drosophila melanogaster, under different conditions of nucleotide excision repair. Mutat Res 2012; 741: 81-88.

25. Rosell R, Taron M, Barnadas A, Scagliotti G, Sarries C, Roig B. Nucleotide excision repair pathways involved in Cisplatin resistance in non-small-cell lung cancer. Cancer Control 2003; 10: 297-305.

26. Liu RY, Dong Z, Liu J, Yin JY, Zhou L, Wu X et al. Role of elF3a in regulating cisplatin sensitivity and in translational control of nucleotide excision repair of nasopharyngeal carcinoma. Oncogene 2011; 30: 4814-4823.

27. Wang QE, Milum K, Han C, Huang YW, Wani G, Thomale J et al. Differential contributory roles of nucleotide excision and homologous recombination repair for enhancing cisplatin sensitivity in human ovarian cancer cells. Mol Cancer 2011; 10: 24.
28. Aloyz R, Xu ZY, Bello V, Bergeron J, Han FY, Yan Y et al. Regulation of cisplatin resistance and homologous recombinational repair by the TFIIH subunit XPD. Cancer Res 2002; 62 : 5457-5462.

29. Boeckman HJ, Trego KS, Turchi JJ. Cisplatin sensitizes cancer cells to ionizing radiation via inhibition of nonhomologous end joining. Mol Cancer Res 2005; 3: 277-285.

30. Ciccia A, Elledge SJ. The DNA damage response: making it safe to play with knives. Mol Cell 2010; 40: 179-204.

31. Ahmed EA, de Boer P, Philippens ME, Kal HB, de Rooij DG. Parp1-XRCC1 and the repair of DNA double strand breaks in mouse round spermatids. Mutat Res 2010; 683: 84-90.

32. Parsons JL, Tait PS, Finch D, Dianova II, Allinson SL, Dianov GL. CHIP-mediated degradation and DNA damage-dependent stabilization regulate base excision repair proteins. Mol Cell 2008; 29: 477-487.

33. Cho EA, Juhnn YS. The cAMP signaling system inhibits the repair of gamma-ray-induced DNA damage by promoting Epac1-mediated proteasomal degradation of XRCC1 protein in human lung cancer cells. Biochem Biophys Res Commun 2012; 422: 256-262.

34. Kang HC, Lee YI, Shin JH, Andrabi SA, Chi Z, Gagne JP et al. Iduna is a poly(ADP-ribose) (PAR)-dependent E3 ubiquitin ligase that regulates DNA damage. Proc Natl Acad Sci USA 2011; 108: 14103-14108.

35. Plo I, Liao ZY, Barcelo JM, Kohlhagen G, Caldecott KW, Weinfeld M et al. Association of XRCC1 and tyrosyl DNA phosphodiesterase (Tdp1) for the repair of topoisomerase I-mediated DNA lesions. DNA Repair (Amst) 2003; 2: 1087-1100.

36. Tardi PG, Dos SN, Harasym TO, Johnstone SA, Zisman N, Tsang AW et al. Drug ratiodependent antitumor activity of irinotecan and cisplatin combinations in vitro and in vivo. Mol Cancer Ther 2009; 8: 2266-2275.

37. Ajani JA, Walsh G, Komaki R, Morris J, Swisher SG, Putnam JJ et al. Preoperative induction of CPT-11 and cisplatin chemotherapy followed by chemoradiotherapy in patients with locoregional carcinoma of the esophagus or gastroesophageal junction. Cancer 2004; 100: 2347-2354.

38. Ajani JA, Baker J, Pisters PW, Ho L, Mansfield PF, Feig BW et al. Irinotecan/cisplatin in advanced, treated gastric or gastroesophageal junction carcinoma. Oncology (Williston Park) 2002; 16: 16-18.

39. Lara PJ, Natale R, Crowley J, Lenz HJ, Redman MW, Carleton JE et al. Phase III trial of irinotecan/cisplatin compared with etoposide/cisplatin in extensive-stage small-cell lung cancer: clinical and pharmacogenomic results from SWOG S0124. J Clin Oncol 2009; 27: 2530-2535.

40. Wang S, Gong Z, Chen R, Liu Y, Li A, Li G et al. JWA regulates XRCC1 and functions as a novel base excision repair protein in oxidative-stress-induced DNA single-strand breaks. Nucleic Acids Res 2009; 37: 1936-1950.

41. Zhou J, Ye J, Zhao X, Li A, Zhou J. JWA is required for arsenic trioxide induced apoptosis in HeLa and MCF-7 cells via reactive oxygen species and mitochondria linked signal pathway. Toxicol Appl Pharmacol 2008; 230: 33-40.

42. Shen L, Xu W, Li A, Ye J, Zhou J. JWA enhances As(2)O(3)-induced tubulin polymerization and apoptosis via p38 in HeLa and MCF-7 cells. Apoptosis 2011; 16: 1177-1193.

43. Okamoto H, Li J, Vortmeyer AO, Jaffe H, Lee YS, Glasker S et al. Comparative proteomic profiles of meningioma subtypes. Cancer Res 2006; 66: 10199-10204.

44. Weichert W, Roske A, Gekeler V, Beckers T, Ebert MP, Pross M et al. Association of patterns of class I histone deacetylase expression with patient prognosis in gastric cancer: a retrospective analysis. Lancet Oncol 2008; 9: 139-148.

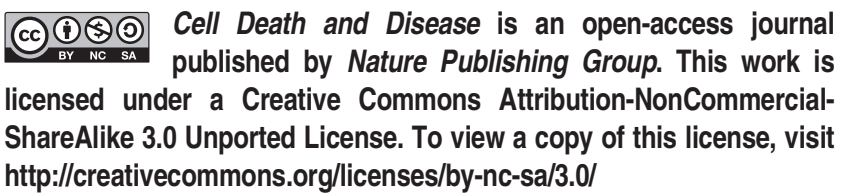
http://creativecommons.org/licenses/by-nc-sa/3.0/

Supplementary Information accompanies this paper on Cell Death and Disease website (http://www.nature.com/cddis) 